\title{
DETECTION OF HEAVY METALS IN FARMED CHERAX DESTRUCTOR
}

\author{
G. BRUNO (1), M.G. VOLPE (1), G. DE LUISE (2), M. PAOLUCCI (2)*
}

(1) Istituto di Scienze dell'Alimentazione, CNR, via Roma, 83100 Avellino, Italy.

(2) Dipartimento di Scienze Biologiche ed Ambientali, Università del Sannio, via Port'Arsa, 11, 82100 Benevento, Italy.

* Corresponding author: Prof. Marina Paolucci, Dept. of Biological and Environmental Sciences, Faculty of Sciences, via Port'Arsa 11, University of Sannio, 82100 Benevento, Italy. Tel.: 0824-305126 - Fax: 0824-23013. E-Mail: Paolucci@unisannio.it

Reçu le 24 juin 2006

Accepté le 13 mars 2006

Received June 24, 2006

Accepted March 13, 2006

\section{ABSTRACT}

Crayfish utilize aquatic plants as a food source and may concentrate pollutants, such as heavy metals. Monitoring the possible heavy metal presence in crayfish edible tissues is therefore important since crayfish can be part of the human diet. In this study we have analysed specimens of Cherax destructor of two different sizes coming from a crayfish farm, with respect to heavy metal (lead, copper, cadmium, chromium, zinc) concentrations in the muscle, hepatopancreas and exoskeleton. Furthermore, the metal concentrations were determined in water, sediment and in plants.

Our data show that the contents of lead, copper, cadmium, chromium and zinc, are higher in the tissues with respect to water, indicating in some cases their bioaccumulation in Cherax destructor. The content of lead and zinc in sediment and plants the animals feed on, was higher than in tissues and organs, suggesting that biomagnification does not occur for these heavy metals. Copper and chromium show biomagnification in all tissues, while cadmium only in the hepatopancreas.

Key-words: Cherax destructor, heavy metals, bioaccumulation, biomagnification.

\section{DÉTERMINATION DE MÉTAUX LOURDS DANS L'ÉCREVISSE CHERAX DESTRUCTOR EN ÉLEVAGE}

\section{RÉSUMÉ}

Les écrevisses s'aliment de plantes aquatiques. En conséquence, ils peuvent accumuler des substances polluantes comme les métaux lourds. Analyser la présence éventuelle de métaux lourds dans la part comestible des écrevisses est donc important, car ils sont utilisés pour l'alimentation humaine. Dans ce travail nous avons évalué la présence de métaux lourds (plomb, cuivre, cadmium, chrome et zinc) dans le muscle, dans l'hépatopancréas et dans l'exosquelette de l'espèce d'élevage Cherax destructor. Les organismes étudiés ont été répartis en deux groupes sur la base de leur taille. De plus, nous avons évalué la présence de métaux lourds dans l'eau, dans le sédiment et dans la végétation aquatique. Nos données montrent que la concentration en plomb, 
cuivre, cadmium, chrome et zinc est plus importante dans les tissus que dans l'eau. On en conclut que se produit une bioaccumulation. La concentration en plomb et en zinc relevées dans les sédiments et les plantes aquatiques dont les écrevisses se nourrissent, est plus élevée que celles relevées dans les tissus et dans les organes, et cela fait supposer que le phénomène de bioamplification dans tous les tissus ne se produit pas pour ces éléments. Cuivre et Chromium sont biomagnifiés, alors que le cadmium ne le fait que dans l'hépatopancréas.

Mots-clés : Cherax destructor, métaux lourds, bioaccumulation, bioamplification.

\section{INTRODUCTION}

Heavy metals include a great variety of chemical elements that typically occur in low or trace amounts in the environment, all of which have the potential to provoke toxic effects in organisms. Trace metals occur in nature, (CHAPMAN, 1996) for example dissolved in water, yet capable of exerting biological effects at very low concentration. The term trace metal is used to indicate both essential and non-essential metals. All metals are toxic above a threshold bioavailability (RAINBOW, 1993). Metal uptake usually occurs in aquatic invertebrates by one or two routes, either from solution - through permeable surfaces, such as gills or the digestive tract - or from food, or both pathways direct and trophic (HARE, 1992; ROY and HARE, 1999; SIMON and BOUDOUN, 2001). The importance of each possible route, food or water, depends on the physiology of the organisms concerned, prey/predator, the geochemistry of the metal involved and physicochemical parameters of the environment. Routes of uptake may, therefore, vary between organisms and between metals for the same organism (LANGSTON and SPENCE, 1995; BLACKMORE and MORTON, 2002).

Water quality criteria based solely on toxicity studies of dissolved contaminants may be inappropriate when accumulation from food is important. The tissue distribution of metals differs with the source of uptake. A metal that is mainly taken up from food is expected to become concentrated in the body tissues (FISHER and REINFELDER, 1995), or if the metals are taken up from solution they are absorbed onto exoskeleton (MIRAMAND and BENTLEY, 1992), although metals absorbed by water or trophic can be accumulated in the same organ. Indeed, water exposure leads to an accumulation in gills and in hepatopancreas (ANDERSON et al., 1997).

In general, the metal concentrations tend to be higher in the hepatopancreas than in muscle tissue, although the reverse is sometimes true for zinc (POURANG et al., 2004). One fact that seems to have a relatively constant effect is the size of the animal, with the larger (and presumably older) individuals containing greater concentrations of metals (POURANG et al., 2004). Crustaceans, like all aquatic invertebrates, take up and accumulate metals from a wide range of sources and the trace metal concentrations within their tissues and bodies show great variability (TUROCZY et al., 2001). In Daphnia magna Cd uptake from water and food has been demonstrated to be independent of exposure source and can lead to an additive effect. In addition, the efficiency with which Cd was assimilated by Daphnia magna from its algal diet was much higher than from water (BARATA et al., 2002). In the crab Portunus pelagicus significant Cd accumulation was detected after 4 weeks of feeding with contaminated food (McPHERSON and BROWN, 2001). The relative importance of dissolved water pathway and food pathway and the influence of food type in the bioaccumulation and retention of lead has been demonstrated in the shrimp Palaemonetes varians (BOISSON et al., 2003). In particular, a study carried out on the crayfish Austropotamobius pallipes and Pacifastacus leniusculus has shown a positive correlation between the environmental conditions and the heavy metal contents of these animals (ANTÒN et al., 2000). 
Despite the importance of the freshwater crayfish industry worldwide, relatively little information is available on the presence of metals, particularly through dietary exposure on crayfish (ALMAR et al., 1987; ALLINSON et al., 2000; MANN et al., 2004; PENNUTO et al., 2005). Crayfish farmed in ponds, utilize aquatic plants as a food source and therefore represent a high trophic level and a link between the uptake of pollutants by aquatic plants and their eventual consumption by humans. Aquatic plants are well known for their ability to accumulate metal ions (DIRILGEN and INEL, 1994; DEVI et al., 1996).

Usually in farmed crayfish the water quality is the main element of concern. However, metal concentrations, although often present, are under the level of detectability. Furthermore, water characteristics may change over time. Hence, the importance of monitoring the possible metal presence in crayfish and especially in the edible tissues may be of dietary concern with respect to their ability to concentrate metals. Therefore, in this study we have analysed specimens of Cherax destructor of two different sizes coming from a crayfish farm, with respect to heavy metal (lead, copper, cadmium, chromium, zinc) concentrations in the muscle, hepatopancreas and exoskeleton. Furthermore, the metal concentrations were determined in water, sediment and in plants.

\section{MATERIALS AND METHODS}

\section{Crayfish, sediment and plant collection.}

10 juveniles (about 10 grams) and 10 adults (about 50 grams) of Cherax destructor were collected from a commercial farm (Azienda Agricola Antonio Zannini, Marocco di Mogliano, TV, Italy). The crayfish were sacrificed immediately after capture and samples of muscle, exoskeleton and hepatopancreas were collected and stored at $-80^{\circ} \mathrm{C}$. Samples of water, sediment and plants (Myriophyllum aquaticum, Elodea Canadensis, Chara spp.) were also collected for heavy metal content analysis.

\section{Heavy metal content evaluation}

Three grams of sample were placed in china cap, weighed and heated in furnace to $105^{\circ} \mathrm{C}$. Then, the sample was cooled in dry atmosphere for 40 minutes and weighed. The sample was carbonated by small flame, put in muffle to $550^{\circ} \mathrm{C}$ for some hours and cooled in dry atmosphere for 40 minutes. The obtained ashes were dissolved in hydrochloride acid solution and put in hot water bath and finally filtered. Distilled water was added up to $50 \mathrm{ml}$ and the sample underwent heavy metal content evaluation. A Spectrophotometer Varian AA-200 was used for this work along with flame burner and with the Varian GTA-100 graphite furnace atomizer. We used Graphite Furnace AA for lead $(\mathrm{Pb})$ and cadmium $(\mathrm{Cd})$, and flame burner for chromium $(\mathrm{Cr})$, copper $(\mathrm{Cu})$ and zinc (Zn) determinations. Nitrogen was used as the inert gas with Graphite Furnace because it not only offers advantages for most elements in terms of sensitivity, but also it provides a good protection for the graphite and air and acetylene when we used flame burner for determinations. The hollow cathode metal lamps were used at opportune wavelength: the copper lamp at $324.8 \mathrm{~nm}$, the cadmium lamp at $228.8 \mathrm{~nm}$, the chromium lamp at 357.9, the zinc lamp at $213,9 \mathrm{~nm}$, the lead lamp at $217.0 \mathrm{~nm}$. Water was Tracepur (Merck) for inorganic trace analysis. Metal atomic absorption standard solutions with lead, cadmium, copper, zinc, chromium as solutes, in the forms of $1,000 \mathrm{ppm}$ solution, (Solution Plus, INC.) were used to prepare the working standard for the programmable sample dispenser. The final concentration of nitric acid in all the solutions was $0.5 \% \mathrm{v} / \mathrm{v}$. A new rational calibration procedure was selected on the Spectrophotometer AA in order to assess the amount of metal in the samples. A calibration graph was produced for each metal so that the maximum absorbance, calibration linearity and working range could be properly assessed. The detailed procedure is provided by "Analytical Methods for Graphite Tube Atomizers" (Varian, 1988) and successfully used by one of the authors (AVELLA 
et al., 2005). Experiments were run in triplicates and the following detection limits were employed: lead $(0.1-30 \mu \mathrm{g} / \mathrm{mL})$, cadmium $(0.02-3 \mu \mathrm{g} / \mathrm{mL})$, copper $(0.03-10 \mu \mathrm{g} / \mathrm{mL})$, zinc (0.01-2 $\mu \mathrm{g} / \mathrm{mL})$, chromium (0.06-15 $\mu \mathrm{g} / \mathrm{mL})$.

\section{RESULTS}

In Table 1 the metal contents $(\mathrm{Pb}, \mathrm{Cd}, \mathrm{Cr}, \mathrm{Cu}, \mathrm{Zn})$ are reported in both juvenile and adult tissues (muscle, exoskeleton and hepatopancreas). The relative amount is the ratio between burden in organ and total burden accumulated in whole body of lead in different tissues was similar between juveniles and adults. The lead content was, in both juveniles and adults, higher in the hepatopancreas than in the muscle and in the exoskeleton.

\section{Table I}

Heavy metal concentrations $(\mathbf{m g} / \mathbf{k g})$ in Cherax destructor.

\section{Tableau I}

Concentration de métaux lourds $(\mathbf{m g} / \mathbf{k g})$ chez Cherax destructor.

\begin{tabular}{|l|c|c|c|c|c|c|}
\hline Sample & $\begin{array}{c}\mathrm{Pb} \\
\text { Muscle } \\
\text { Average } \pm \text { S.D. }\end{array}$ & $\begin{array}{c}\mathrm{Pb} \\
\text { Exoskeleton } \\
\text { Average } \pm \text { S.D. }\end{array}$ & $\begin{array}{c}\mathrm{Pb} \\
\text { Hepatopancreas } \\
\text { Average } \pm \text { S.D. }\end{array}$ & $\begin{array}{c}\text { Cd } \\
\text { Muscle } \\
\text { Average } \pm \text { S.D }\end{array}$ & $\begin{array}{c}\text { Cd } \\
\text { Exoskeleton } \\
\text { Average } \pm \text { S.D. }\end{array}$ & $\begin{array}{c}\text { Cd } \\
\text { Hepatopancreas } \\
\text { Average } \pm \text { S.D. }\end{array}$ \\
\hline $\begin{array}{l}\text { Juveniles } \\
\mathrm{n}=10\end{array}$ & $0.26 \pm 0.13$ & $0.63 \pm 0.95$ & $2.91 \pm 1.01$ & $0.02 \pm 0.02$ & $0.05 \pm 0.01$ & $9.2 \pm 2.85$ \\
\hline $\begin{array}{l}\text { Adults } \\
\mathrm{n}=10\end{array}$ & $0.38 \pm 0.31$ & $0.70 \pm 0.32$ & $2.11 \pm 0.93$ & $0.45 \pm 0.26$ & $2.21 \pm 1.20$ & $9.80 \pm 2.56$ \\
\hline
\end{tabular}

\begin{tabular}{|l|c|c|c|c|c|c|}
\hline & $\begin{array}{c}\mathrm{Cr} \\
\text { Muscle }\end{array}$ & $\begin{array}{c}\mathrm{Cr} \\
\text { Exoskeleton }\end{array}$ & $\begin{array}{c}\mathrm{Cr} \\
\text { Hepatopancreas }\end{array}$ & $\begin{array}{c}\mathrm{Cu} \\
\text { Muscle }\end{array}$ & $\begin{array}{c}\mathrm{Cu} \\
\text { Exoskeleton }\end{array}$ & $\begin{array}{c}\mathrm{Cu} \\
\text { Hepatopancreas }\end{array}$ \\
\hline $\begin{array}{l}\text { Juveniles } \\
\mathrm{n}=10\end{array}$ & $6.18 \pm 1.12$ & $14.42 \pm 5.47$ & $38.22 \pm 10.87$ & $12.15 \pm 5.74$ & $16.80 \pm 5.21$ & $18.27 \pm 9.43$ \\
\hline $\begin{array}{l}\text { Adults } \\
\mathrm{n}=10\end{array}$ & $4.35 \pm 0.99$ & $14.41 \pm 4.53$ & $60.10 \pm 19.97$ & $7.82 \pm 2.89$ & $15.50 \pm 4.91$ & $17.94 \pm 7.98$ \\
\hline
\end{tabular}

\begin{tabular}{|l|c|c|c|l|l|l|}
\hline & $\begin{array}{c}\text { Zn } \\
\text { Muscle }\end{array}$ & $\begin{array}{c}\text { Zn } \\
\text { Exoskeleton }\end{array}$ & $\begin{array}{c}\text { Zn } \\
\text { Hepatopancreas }\end{array}$ & & & \\
\hline $\begin{array}{l}\text { Juveniles } \\
\mathrm{n}=10\end{array}$ & $38.14 \pm 16.53$ & $29.61 \pm 9.21$ & $75.70 \pm 21.96$ & & & \\
\hline $\begin{array}{l}\text { Adults } \\
\mathrm{n}=10\end{array}$ & $3.60 \pm 1.77$ & $20.70 \pm 5.89$ & $50.20 \pm 14.11$ & & & \\
\hline
\end{tabular}

$\mathrm{n}=$ number of samples analyzed.

The relative amount of cadmium was higher in the muscle and in the exoskeleton of the adults, compared to the juveniles. On the other hand, the amount of cadmium in the hepatopancreas was similar in the juveniles and adults and much higher than the cadmium content reported in the muscle and in the exoskeleton.

The chromium content was slightly higher (no statistical tests were run at this stage) in the muscle of the juveniles than in the adults, while was almost as twice as much in the hepatopancreas of the adults compared to the juveniles. The relative amount of chromium was similar in the exoskeleton of the juveniles and adults. The metal content in the hepatopancreas was much higher than in the other tissues. 
The amount of copper was slightly higher in all tissues of the juveniles compared to the adults and in the hepatopancreas of both juveniles and adults with respect to the other tissues.

The relative amount of zinc was much higher in all tissues of juveniles compared to the adults, and higher in the hepatopancreas of both juveniles and adults compared to the other tissues.

In sediment (Table 2) all the metals were present and the concentrations of lead, cadmium and zinc were much above the maximum concentration allowed by the law DM $471 \backslash 1999(5 \mathrm{mg} / \mathrm{kg}, 0.1 \mathrm{mg} / \mathrm{kg}$, and $5 \mathrm{mg} / \mathrm{kg}$, respectively). On the other hand, the concentrations of chromium and copper were within the levels allowed by the law DM 471\1999 (5 mg/kg in both cases), although the chromium level in sediment was slightly higher $(5.3 \mathrm{mg} / \mathrm{kg})$. In water and plants all metals were present, except for chromium which was not detectable in water. The heavy metal concentrations were lower in water and plants than in the sediment (Table 2).

\section{Table II}

Heavy metal concentrations $(\mathrm{mg} / \mathrm{kg})$ in the sediment and plants and heavy metal concentration $(\mu \mathrm{g} / \mathrm{l})$ in the water.

\section{Tableau II}

Concentrations en métaux lourds $(\mathrm{mg} / \mathrm{kg})$ dans les sédiments et les plantes et concentration en métaux lourds ( $\mu \mathrm{g} / \mathrm{l})$ dans l'eau.

\begin{tabular}{|l|c|c|c|c|c|}
\hline \multicolumn{1}{|c|}{ Sample } & $\begin{array}{c}\mathbf{P b} \\
\text { Average } \pm \text { S.D. }\end{array}$ & $\begin{array}{c}\text { Cd } \\
\text { Average } \pm \text { S.D. }\end{array}$ & $\begin{array}{c}\mathbf{C r} \\
\text { Average } \pm \text { S.D. }\end{array}$ & $\begin{array}{c}\mathbf{C u} \\
\text { Average } \pm \text { S.D. }\end{array}$ & $\begin{array}{c}\mathbf{Z n} \\
\text { Average } \pm \text { S.D. }\end{array}$ \\
\hline $\begin{array}{l}\text { Sediment } \\
\mathrm{n}=3\end{array}$ & $13.91 \pm 5.31$ & $3.37 \pm 1.75$ & $5.31 \pm 1.52$ & $3.03 \pm 1.02$ & $81.34 \pm 9.57$ \\
\hline $\begin{array}{l}\text { Plants } \\
\mathrm{n}=3\end{array}$ & $7.28 \pm 3.07$ & $2.39 \pm 0.65$ & $1.24 \pm 0.89$ & $2.70 \pm 0.79$ & $55.77 \pm 3.65$ \\
\hline $\begin{array}{l}\text { Water } \\
\mathrm{n}=3\end{array}$ & $3.80 \pm 1.06$ & $1.58 \pm 0.32$ & n.d. & $23.71 \pm 5.43$ & $93.20 \pm 8.67$ \\
\hline
\end{tabular}

n.d. $=$ not detectable; $\mathrm{n}=$ number of samples analyzed.

\section{DISCUSSION}

In this study we present data about bioaccumulation and biomagnification of heavy metals in farmed Cherax destructors. Lead, cadmium, chromium, copper and zinc were measured in muscle, exoskeleton, and hepatopancreas of juveniles and adults, along with the metal contents in water, sediment and plants. Bioaccumulation is an increase in concentration of a toxicant in organs and tissues in excess of what is normally expected. The toxicant is bioconcentrated if its concentration in organs and tissues exceeds those of the surrounding air or water. Biomagnification refers to an enhancement of toxicant concentrations in tissues and organs at each successive level in a food chain (KELLY et al., 2004). Our data show that the contents of heavy metals, are higher in the tissues with respect to water, indicating their bioaccumulation in Cherax destructor. Conversely, their contents in sediment and plants the animals feed on, are in some cases (Pb, Zn) higher than those detected in tissues and organs, suggesting that biomagnification does not occur for all metals. 
Copper is an essential micronutrient for most organisms. Plants with less than $5 \mathrm{mg} / \mathrm{kg}$ can lead to copper deficiency in sheep and cattle, but with greater than $10 \mathrm{mg} / \mathrm{kg}$ toxicity will occur in sheep (GRACE and WILSON, 2002). Although it is also considered toxic in many aquatic organisms, this metal is an essential constituent of the crayfish respiratory pigment. Hence, the relatively high levels of these metals can be attributed to their essentiality. In our study, the copper concentration in the sediment was below the level permitted by the law and in the plants it was even lower. However, both juveniles and adults accumulated copper in their tissues, especially in the hepatopancreas. However, it should be kept in mind that since copper is an essential metal, its supposed bioaccumulation should be discussed in comparison with the level of copper in control specimens. Our results are not in contrast with what reported by ALLINSON et al. (2000) in their study on the bioaccumulation of dietary copper in Cherax destructor fed with contaminated plants. Indeed, high copper concentrations were reported in gills, hemolymph and muscle, and in the hepatopancreas, although the accumulation in this organ is not among the higher level. We hypothesize that the discrepancy between our results and those reported by ALLISON et al. (2000) is due to the short experimental period the animals underwent (3 weeks) in the study carried out by ALLISON et al (2000). Although we have no precise indication about the length of stay in the rearing ponds of the specimens used in our experiment, the time is undoubtedly longer than three weeks. Indeed, juveniles were born in captivity and adults were at least five month old. Our hypothesis is also supported by the results reported by ANTÒN et al. (2000) on the relationship between metal content in crayfish and environment conditions (water and sediment), which confirm copper bioaccumulation in Austropotamobius pallipes and Pacifastacus leniusculus. Strangely, the same authors report no bioaccumulation for cadmium and chromium in the same species, although the chromium concentration in the sediment was consistent. Indeed, both metals were under the level of detectability in the muscle and in the exoskeleton. In our study, chromium levels in the sediment and in the plants was lower than in the tissues especially in the hepatopancreas, suggesting both bioaccumulation and biomagnification. Cadmium levels were three times higher in the hepatopancreas compared to the sediment and four times higher compared to the plants, suggesting biomagnification for this metal. This result is in good agreement with that reported for the crab Portumus pelagicus (McPHERSON and BROWN, 2001). Food has been found to be an important source of cadmium for crustaceans (VAN HATTUM et al., 1989; REINFELDER and FISHER, 1991; BARATA et al., 2002) with assimilation efficiencies ranging from 1 to $30 \%$. In Cherax destructor, cadmium concentration in the muscle of juveniles and adults and in the exoskeleton of juveniles were definitely lower than in the sediment and in the plants, which indicates that these animals actively eliminate the metal. The relatively high amount of cadmium in the exoskeleton of adults could be attributed to the lower frequency of moulting respect to juveniles. Indeed, the exoskeleton may contain a significant proportion of the total body burden of metals, but this may be reduced prior to moulting. Thus, the extending of this loss is uncertain (MANCE, 1990). STEENKAMP et al. (1994) found variation in the carapace manganese concentration of Potamonautes warreni, likely related to the stage in the moult cycle. HILMY et al. (1988) reported that mature crabs, Portunus pelagicus accumulated higher concentrations of zinc than immature crabs. This is also true for the shrimp Penaeus vannamei (PAEZ-OSUNA and TRON-MAYEN, 1996) and can be related to the lower frequency of moulting in the adults. Differently, we found that juveniles accumulated more zinc than adults. We can hypothesize that physiological needs can change between juvenile and adults. particularly in the light that zinc is an essential metal On the contrary, LEE et al. (1998) found that zinc uptake in bivalves was not significantly related to the body size.

Lead and particularly zinc are both present in the sediment and in the plants, however, their concentrations in the tissues of Cherax destructor are lower, especially in the muscle and in the exoskeleton, compared to the hepatopancreas, indicating no bioaccumulation for these two metals. This is partially sustained by a study carried out 
in the shrimp Palaemonetes varians, by BOISSON et al. (2003) indicating a relatively low bioavailability of lead from contaminated food. We should indeed consider that the presence of accumulated lead in the internal tissues is probably due to gut absorption from contaminated seawater needed for osmotic regulation, and that this physiological process does not attain the freshwater crayfish.

\section{CONCLUSION}

In conclusion, in this study we report data on heavy metal concentrations in farmed Cherax destructor. Our data show that both bioaccumulation and biomagnification can occur in edible tissues. This may lead to some dietary concern since crayfish are part of the human diet, however, their role in human diet is very limited at least in our country. Therefore we conclude that, although heavy metals are present in crayfish, this should not represent a source of preoccupation for crayfish consumers.

\section{AKNOWLEDGEMENTS}

This investigation was supported by a Grant to Prof. Marina Paolucci, from the Regione Campania, Assessorato Agricoltura, Caccia e Pesca.

\section{REFERENCES}

ALLINSON G., LAURENSON L., PISTONE G., STAGNITTI F., JONES P., 2000. Effects of Dietary Copper on the Australian Freshwater Crayfish Cherax destructor, Ecotoxicology and Environmental Safety. Vol. 46, pp. 117-123, Academic Press, California, USA.

ALMAR M.M., DIAZ-MAIANZ J., ROMERO F.J., 1987. Glutathione content and GSH Stransferase activity in midgut gland of Procambarus clarkii. Sex differences, the effect of fasting, and their implications in cadmium toxicity. Comp Biochem Physiol C., 87, 433-435.

ANDERSON M.B., REDDY P., PRESLAN J.E., FINGERMAN M., BOLLINGER J., JOLIBOIS L., MAHESHWARUDU G, GEORGE W.J., 1997. Metal accumulation in crayfish, Procambarus clarkii, exposed to a petroleum-contaminated Bayou in Louisiana. Ecotoxicol Environ Saf, 37, 267-272.

ANTÒN A., SERRANO T., ANGULO E., FERRERO G., RALLO A., 2000. The use of two species of crayfish as environmental quality sentinels: the relationship between heavy metal content, cell and tissue biomarkers and physico-chemical characteristics of the environment. The Science of the Total Environment., 247, 239-251.

AVELLA M., DE VLIEGER J.J., ERRICI M.E., FISCHER S., VACCA P., VOLPE M.G., 2005. Biodegradable Starch/Clay Nanocomposites for food packaging applications. Food Chemistry, 93, 467-474.

BARATA C., SCOTT J.M., DONALD J.B., AMADEU M.V.M.S., 2002. The relative importance of water and food as cadmium sources to Daphnia magna Straus. Aquatic Toxicology, 61, 143-154.

BLACKMORE G., MORTON B., 2002. The influence of diet on comparative trace metal cadmium, copper and zinc accumulation in Thais clavigera (Gasteropoda: Muricidae) preying on intertidal barnacles or mussels. Marine pollution Bulletin, 44, 870-876.

BOISSON F., COTRET O., TEYSSIÈ J.L., EL-BARADEI M., FOWLER S.W., 2003. Relative importance of dissolved and food pathways for lead contamination in shrimp. Marine Pollution Bulletin, 46, 1549-1557. 
CHAPMAN D, Editor., 1996. Water quality assessments. A guide to the use of biota sediments and water in environmental monitoring. $2^{\text {nd }}$ ed. In: SPON E, FN. London: Chapman and Hall, 1996: 626.

DEVI M., THOMAS D.A., BARBER J.T., FINGERMAN M., 1996. Accumulation an physiological and biochemical effects of cadmium in a simple aquatic food chain. Ecotoxicology and Environmental Safety, 33, 38-43.

DIRILGEN N., INELY., 1994. Effects of zinc and copper on growth and metal accumulation in Duckweed, lemna minor. Bull. Environ. Contam. Toxicol., 53, 442-449.

FISHER N.S., REINFELDER J.R., 1995. The trophic transfer of metals in marine systems. In: Metal Speciation and Bioavailability in Aquatic Systems, A.TESSIER and D.R. TURNER (Eds.), John Wiley \& Sons, Chichester, 363-406.

GRACE N.D., WILSON P.R., 2002. Trace element metabolism, dietary requirements, diagnosis and prevention of deficiencies in deer. N. Z. Vet. J., 50, 252-259.

HARE L., 1992. Aquatic insects and trace metals: bioavailability, bioaccumulation and toxicity. Crit. Rev. Toxicol., 22, 327-369.

HILMY A.M., ABD EL-HAMID N.F., GHAZALY K.S., 1988. Variation of zinc and copper levels with sex and size in different tissues of crab Portunus pelagicus (Linnaeus). Folia Morphologica, 2, 160-166.

VAN HATTUM B., DE VOOGT P., VAN DEN BOSH L., VAN STRALEEN N.M., JOOSSE E.N.G., 1989. Bioaccumulation of cadmium by the fresh water isopod Asellus aquaticus (L.) from aqueous and dietary sources. Environ. Poll., 62, 129-151.

KELLY B.C., GOBAS F.A., MCLACHLAN M.S., 2004. Intestinal absorption and biomagnification of organic contaminants in fish, wildlife, and humans. Environ Toxicol. Chem., 23, 2324-2336.

LANGTON W.J., SPENCE S.K., 1995. Biological factors involved in metal concentrations observed in aquatic organisms. Metal Speciation and Bioavailability in Aquatic Systems, pp. 407-478.

LEE B.G., WALLACE W.G., LUOMA S.N., 1998. Uptake and loss kinetics of Cd, Cr, and Zn in the bivalves Potamocorbula amurensis and Macoma baltica: effects of size and salinity. Mar. Ecol. Prog. Ser., 175, 177-189.

MANCE G., 1990. Pollution threat of heavy metals in aquatic environments, $372 \mathrm{p}$. Elsevier.

MANN R.M., GROSSEL M., BIANCHINI A., WOOD C.M., 2004. Biologically incorporated dietary silver has no ionoregulatory effects in American red crayfish (Procambarus clarkii). Environ Toxicol Chem., 23, 388-395.

McPHERSON R., BROWN K., 2001. The bioaccumulation of cadimuim by the Blue Swimmer Crab Portunus pelagicus L. The Science of the Total Environment., 279, 223-230.

MIRAMAND P., BENTLEY D., 1992. Concentration and distribution of heavy metals in tissues of two cephalopods, Eledone cirrhosa and Sepia officinalis, from the French coast of the English Channel. Mar. Biol., 114, 407-414.

PAEZ-OSUNA F., TRON-MAYEN L., 1996. Concentration and distribution of heavy metals in tissues of wild and farmed shrimp Penaeus vannamei from the northwest coast Mexico. Environ. Int., 22, 443-450.

PENNUTO C.M., LANE O.P., EVERS D.C., TAYLOR R.J., LOUKMAS J., 2005. Mercury in the northern crayfish, Orconectes virilis (Hagen), in New England, USA. Ecotoxicology, $14,149-162$. 
POURANG N., DENNIS J.H., GHOURCHIAN H., 2004. Tissue distribution of trace elements in shrimp species with the emphasis on the roles of metallothioneins. Ecotoxicology, 13, 519-533.

RAINBOW P.S., 1993. The significance of trace metal concentrations in marine invertebrates. In: DALLINGER R., RAINBOW P.S., editors. Ecotoxicology of metals in invertebrates. Boca Raton: Lewis Publishers, pp. 3-23.

REINFEFELDR J.R., FISHER N.S., 1991. The assimilation of elements ingested by marine copepods. Science, 251, 794-796.

ROY I., HARE L., 1999. Relative importance of water and food as cadmium sources to the predatory insects Sialis velata (Megaloptera). Can.J.Fish. Aquat. Sci., 56, 11431149.

SIMON O., BOUDOUN A., 2001. Simultaneous experimental study of direct and direct plus trophic contamination of the crayfish Astacus astacus by inorganic mercury and methylmercury. Environ Toxicol Chem., 20, 1206-1215.

STEENKAMP V.E., du PREEZE H.H., SCHOONBEE H.J., van EDEN P.H., 1994. Bioaccumulation of manganese in selected tissues of the freshwater crab Potamonautes warreni (Calman), from industrial and mine-polluted freshwater ecosystems. Hydrobiologica, 288, 137-150.

TUROCZY N.J., MITCHELL B.D., LEVINGS A.H., RAJENDRAM V.S., 2001. Cadmium, copper, mercury and zinc concentration in tissues of the King Crab (Pseudocarcinus gigas) from southeast Australian waters. Environ. International, 27, 327-334. 
